\title{
Mortality of Bemisia tabaci Biotype B (Sternorrhyncha: Aleyrodidae) Adults by Aliphatic and Aromatic Synthetic Sucrose Esters
}

\author{
Mariangela Alves ${ }^{1}$, Maurício Boscolo ${ }^{2}$, Odair Aparecido Fernandes ${ }^{3 *}$ and Maria Andréia \\ Nunes ${ }^{3}$ \\ ${ }^{1}$ Departamento de Tecnologia; Universidade Estadual Paulista; 14884-900; Jaboticabal - SP - Brasil. \\ ${ }^{2}$ Departamento de Química e Ciências Ambientais; Universidade Estadual Paulista; boscolo@qca.ibilce.unesp.br; \\ 15054-000; São José do Rio Preto - SP - Brasil. ${ }^{3}$ Departamento de Fitossanidade; Universidade Estadual Paulista; \\ oafernandes@fcav.unesp.br;14884-900; Jaboticabal-SP - Brasil
}

\begin{abstract}
The B-strain of Bemisia tabaci Gennadius is a key pest of several crops and chemical control is the main control method used by growers, although reduction in efficacy due to insecticide resistance has already been reported. The aim of this work was to investigate the insecticidal effect of an array of synthetic sucrose esters with the aliphatic and aromatic groups on whitefly adults. Sucrose butyrate, caprate, octanoate, palmitate, oleate, octaacetate, phthalate, benzoate, and sucrose diacetate hexaisobutyrate were tested. The solutions were prepared and applied on the adults caught on yellow sticky traps using the Potter spray tower. Long-chains sucrose aliphatic esters were more effective against the silverleaf whiteflies and the highest mortality was obtained with sucrose oleate and sucrose octanoate. Since these compounds were tensoactive, sodium dodecylsulphate was also tested for the comparison but no effect was observed. Sucrose butyrate and other aliphatic and aromatic sucrose polyesters showed negligible effect on the silverleaf whiteflies.
\end{abstract}

Key words: Sucroesters, silverleaf whitefly, pest control, integrated pest management

\section{INTRODUCTION}

The whitefly, Bemisia tabaci (Gennadius) is a non-endemic and polyphagous pest of more than 500 species of the crops, vegetables, and ornamental plants (e.g., soybean, tomato, cotton, melon, and poinsettia) (Sundaramurthy, 1992; Fernandes, 1998). This pest is responsible for the direct and indirect damages to the crops. It is also a vector of several viruses (Brown and Czosnek, 2002). Initially, two biotypes (A and B) were described for Bemisia tabaci (Drost et al., 1998) but presently, several biotypes have been described. The infestation of B-biotype, classified as one of the most aggressive, occurred in the early 1990's in Brazil and increased tremendously during the next years (Lourenção and Nagai, 1994).

Whitefly chemical control is challenging because it causes natural enemies mortality (Michaud and McKenzie, 2004) and insecticide resistance development (Denholm et al., 2003; Gunning,

\footnotetext{
* Author for correspondence
} 
2003). Furthermore, the latter has been a key factor for whitefly outbreaks (Prabhaker et al., 2003). Sucrose esters have been claimed as an alternative strategy to control the aphids and softbodied insects. The insecticidal activity of some natural and synthetic sucroesters has been reported (Liu et al., 1996; Chortyk et al., 1997). The natural sucroesters were obtained from several species of Nicotiana and Petunia. These sucroesters were mainly formed by different carboxylic acids whose chains varied from $C_{2}$ to $C_{12}$ (Chortyk et al., 1996; Chortyk et al., 1997). It seems that sucroesters have a physical action on insects. These compounds remove the waxy protective coating of the insect's tegument causing dehydration (Puterka and Severson, 1995). The efficacy of these products increases in high humidity environments or by mixing them with the wetting agents (Xia and Johnson, 1997; Xia et al., 1997). Compared to the conventional pesticides, sucrose esters offer many advantages. However, large scale use of the natural sugar esters as pesticides might not be commercially viable because the amount found in the plants is very low. Nicotiana trigonophylla Dun. shows the highest content, although the concentration is less than $158 \mu \mathrm{g} / \mathrm{cm}^{2}$ of the leaf surface (Chortyk et al., 1996). Therefore, it is necessary to develop new production methodologies for the sugar esters, preferentially by non-pollutant processes.

Sucrose esters can be produced by combining the common table sugar with (i) fatty acid chlorides (Thévenet et al., 1999), (ii) anhydrides (Gaertner, 1961), and (iii) methyl fatty acid esters or vegetables/animals glycerides by the transesterification process (Schuchardt et al., 1998; Polat and Linhardt, 2001). Because soybean oil contains mainly unsaturated long-chain fatty acids (oleic and linoleic acids) and a review of the literature indicated a lack of the studies on the insecticidal properties of sucrose oleate and sucrose linoleate on several arthropods, the aim of this work was to evaluate the effectiveness of sucrose oleate and an array of the synthetic sucrose esters on the mortality of the adult silverleaf whiteflies and to compare their toxicity with sucrose octanoate, the sole sucroester registered for the pesticide use with the Environmental Protection Agency (EPA) registration (\#70950).

\section{MATERIALS AND METHODS}

Sucrose diacetate hexaisobutyrate (SAIB-100), sucrose octaacetate, sucrose benzoate, sucrose monopalmitate, and sucrose monocaprate were purchased from Sigma-Aldrich (Milwaukee, WI, USA). Sucrose octanoate, sucrose palmitate and sucrose oleate were synthetized by the transesterification reaction of sucrose with the respective fatty acid methyl esters and $\mathrm{K}_{2} \mathrm{CO}_{3}$ as catalyst $\left(10 \% \mathrm{~m} / \mathrm{m}\right.$ of sucrose) at about $90-120^{\circ} \mathrm{C}$ in dimethyl sulphoxide (DMSO) (Polat and Linhardt, 2001). Sucrose phthalate was prepared by reacting the phthalic anhydride with sucrose in DMSO at $80^{\circ} \mathrm{C}$. In all the cases, a stoichiometry of 1.1:1 (sucrose/other reagent) was used to obtain most of the monoesters. The sucroesters production was tracked by the thin layer chromatography using a mixture $\mathrm{CCl}_{3} / \mathrm{MeOH}(5: 1)$ as solvent. The synthesized compounds were isolated by the flash chromatograph silica gel (200 mash.) using acetone/hexane in different proportions as solvent.

The solutions used for the insect treatment were prepared in the water, methanol, ethanol, and acetone as a function of their solubility. The insects were also treated with the pure solvents used in the pulverization or with DMSO. An anionic surfactant, sodium dodecylsulfate (SDS) was also applied for the comparisons.

Whiteflies bioassays were carried out with the adult insects collected from the cabbage plants using the yellow sticky strips with $4 \times 4 \mathrm{~cm}$ of exposed surface (Chortyk et al., 1997). Nine strips (replicates) were used per treatment onto which ca. 15 adults were adhered. The insects were sprayed with $2.0 \mathrm{ml}$ of the test compound solutions using a Potter spray tower (Burkard Manufacturing, Hertfordshire, UK) at $5 \mathrm{lb} / \mathrm{in}^{2}$ pressure. All the treatments were applied at two concentrations (1.0 and $2.0 \mathrm{~g} / \mathrm{L}$ ) (Puterka et al., 2003) for further comparison. After the pulverization, the insects were maintained at $25 \pm 1^{\circ} \mathrm{C}$ and $70 \pm 10 \% \mathrm{RH}$ ) for two hours. A stereoscopic microscope was used to examine the insects, which were considered dead when no movement was observed after gentle probing with a single bristle brush. The percentage mortality was calculated and the analysis of variance was performed (SAS Institute, 1996). The means were separated by the Tukey's test. Data were arcsine $\sqrt{x / 100}$ transformed to stabilize the 
error variance. The mortality was corrected according to Abbott (1925).

\section{RESULTS AND DISCUSSION}

Among the control solutions, ethanol was the most toxic (ca. $10 \%$ of mortality) to adult silverleaf whitefly followed by methanol (ca. 8\%) and acetone $(<4 \%)$ (Table 1$)$. The mortality caused by the DMSO at $2.0 \%(\mathrm{v} / \mathrm{v})$ in water was very low $(<$ $5 \%$ ). Therefore, the possibility of the interference of solvents on the bioassays was negligible. It was observed that only the sucroesters with the alquilic chains with eight or more carbons showed mortality rates higher than $50 \%$. Sucrose octanoate and sucrose oleate caused the highest mortality (> 93\%), followed by sucrose palmitate and sucrose monocaprate. In fact, all these compounds are characterized as surfactants, conversely to the other sucroderivatives tested, indicating that longchain sucrose esters may act on the protective waxy cover of the insects, causing their death. Similar efficacy was expected for a common surfactant, but tests with the SDS showed nonsatisfactory results at $2.0 \mathrm{~g} / \mathrm{L}$ with a mortality rate around $10 \%$ and at $1.0 \mathrm{~g} / \mathrm{L}$ even lower than pure sucrose at the same concentration (Table 1).

Table 1 - Mortality of Bemisia tabaci B-biotype adults caused by sucrose esters and control solutions after $2 \mathrm{~h}$ of application.

\begin{tabular}{|c|c|c|c|c|}
\hline Treatment $^{T}$ & Conc. $(g / L)$ & \multicolumn{2}{|c|}{ Mortality $( \pm \text { SEM })^{2,3}$} & Corrected Mortality \\
\hline Oleate $(\mathrm{MeOH})$ & 2.0 & \multicolumn{2}{|l|}{$100.00 \pm 0.00 \mathrm{a}$} & 100.00 \\
\hline Octanoate & 2.0 & \multicolumn{2}{|l|}{$100.00 \pm 0.00 \mathrm{a}$} & 100.00 \\
\hline Oleate $(\mathrm{EtOH})$ & 2.0 & \multicolumn{2}{|l|}{$99.42 \pm 0.58 \mathrm{a}$} & 99.40 \\
\hline Oleate $(\mathrm{EtOH})$ & 1.0 & \multicolumn{2}{|l|}{$99.35 \pm 0.65 \mathrm{a}$} & 99.33 \\
\hline Octanoate & 1.0 & \multicolumn{2}{|c|}{$93.77 \pm 2.59 \mathrm{ab}$} & 93.64 \\
\hline Unpurified Palmitate $(\mathrm{MeOH})$ & 2.0 & \multicolumn{2}{|c|}{$93.09 \pm 2.54 \mathrm{abc}$} & 92.94 \\
\hline Monopalmitate $(\mathrm{MeOH})$ & 2.0 & \multicolumn{2}{|c|}{$88.08 \pm 4.47 \mathrm{abcd}$} & 87.83 \\
\hline Unpurified Palmitate $(\mathrm{MeOH})$ & 1.0 & \multicolumn{2}{|c|}{$86.89 \pm 3.64 \mathrm{abcd}$} & 86.61 \\
\hline Monocaprate $(\mathrm{MeOH})$ & 2.0 & \multicolumn{2}{|c|}{$83.39 \pm 3.77$ bcde } & 83.04 \\
\hline Monocaprate (MeOH) & 1.0 & \multicolumn{2}{|c|}{$79.11 \pm 4.41$ bcde } & 78.67 \\
\hline Oleate $(\mathrm{MeOH})$ & 1.0 & \multicolumn{2}{|c|}{$78.98 \pm 6.33$ bcde } & 78.54 \\
\hline Monopalmitate $(\mathrm{MeOH})$ & 1.0 & \multicolumn{2}{|c|}{$76.89 \pm 1.62$ bcdef } & 76.40 \\
\hline Oleate (Acetone) & 2.0 & \multicolumn{2}{|c|}{$\begin{array}{rr}76.89 \pm 1.62 & \text { bcdef } \\
67.41 \pm 5.88 & \text { def }\end{array}$} & 66.72 \\
\hline Oleate (Acetone) & 1.0 & $48.81 \pm 3.11$ & fgh & 47.72 \\
\hline SAIB $(\mathrm{MeOH})$ & 2.0 & $38.25 \pm 5.93$ & ghi & 36.94 \\
\hline Benzoate (Acetone) & 1.0 & $35.87 \pm 3.87$ & ghi & 34.51 \\
\hline SAIB $(\mathrm{MeOH})$ & 1.0 & $32.85 \pm 2.46$ & ghi & 31.43 \\
\hline Benzoate (Acetone) & 2.0 & $27.83 \pm 4.48$ & hij & 26.30 \\
\hline Octaacetate (Acetone) & 2.0 & $26.63 \pm 4.28$ & hij & 25.03 \\
\hline Octaacetate (Acetone) & 1.0 & $18.93 \pm 6.19$ & $\mathrm{ijk}$ & 17.21 \\
\hline Ethanol & - & $10.61 \pm 3.84$ & $\mathrm{jkl}$ & 8.72 \\
\hline SDS & 2.0 & $9.53 \pm 3.60$ & $\mathrm{jkl}$ & 7.62 \\
\hline Methanol & - & $8.02 \pm 2.37$ & $\mathrm{jkl}$ & 6.07 \\
\hline Phthalate & 1.0 & $7.67 \pm 2.96$ & $\mathrm{kl}$ & 5.72 \\
\hline Sucrose & 1.0 & $5.79 \pm 2.87$ & $\mathrm{kl}$ & 3.80 \\
\hline Butyrate & 1.0 & $5.38 \pm 1.49$ & $\mathrm{kl}$ & 3.38 \\
\hline Phthalate & 2.0 & $5.21 \pm 1.90$ & $\mathrm{kl}$ & 3.21 \\
\hline DMSO & $2 \% \mathrm{v} / \mathrm{v}$ & $4.44 \pm 2.42$ & $\mathrm{kl}$ & 2.42 \\
\hline SDS & 1.0 & $4.13 \pm 1.93$ & $\mathrm{kl}$ & 2.10 \\
\hline Acetone & - & $3.69 \pm 1.93$ & $\mathrm{kl}$ & 1.65 \\
\hline Butyrate & 2.0 & $2.34 \pm 1.21$ & $\mathrm{kl}$ & 0.27 \\
\hline Water & - & $2.07 \pm 1.05$ & $\mathrm{kl}$ & - \\
\hline Sucrose & 2.0 & $1.74 \pm 1.04$ & 1 & 0.00 \\
\hline
\end{tabular}


Although the hydrophilic-lipophilic balance (HLB) value decreased considerably from monoesters to di- and three-esters, it was no significant variation in the toxicity was found between the high-pure sucrose monopalmitate and a mix of the isomers of an unpurified sucrose palmitate solution. This indicated that the costly purification processes for the pesticide use were not necessary. Puterka et al. (2003) did not find a correlation between the pesticide activity and the HLB value of other types of sugar esters either.

The compounds with high esterification degree (SAIB, sucrose octaacetate, and sucrose benzoate) showed a low mortality and the type of the substitute group (acyl or benzyl) did not affect the mortality rate. Sucrose butyrate and sucrose phthalate were harmless to $B$. tabaci. Long-chain alquilic sucroesters proved to be an interesting strategy for the silverleaf whitefly control because they were cheapwith low environmental impact. The water solubility of sucrose octanoate could be a great advantage over other sucroesters with higher alquilic chain, but the high mortality caused by sucrose oleate associated to the possibility of using a practical and economical source like soybean oil could be a promising proposition. Thus, although Liu et al. (1996) and Chortik et al. (1996) have shown that sucrose esters have insecticidal properties against the whiteflies, this work showed that the longer chain sucroesters of easier making process were also effective against the soft-bodied insects. The next step for this study would be to increase the water solubility of these compounds by using the additives such as the nonpolluter surfactants (Rodriguez et al., 2003). Although these products were appropriate for controlling the adult silverleaf whiteflies, the growers should also consider some other factors prior to the utilization. The effect of sucroesters on plant development, on the seed germination (Peterson et al. 1997), and on the natural enemies should also be investigated.

\section{RESUMO}

O biótipo B de B. tabaci Gennadius tem se destacado como uma praga-chave de diversas culturas. $\mathrm{O}$ controle químico tem sido a principal tática de controle utilizada, embora já se tenha observado redução na eficiência dos produtos devido ao desenvolvimento de resistência. Assim, o objetivo do presente trabalho foi avaliar o efeito de diversos ésteres de sacarose com grupos alifáticos ou aromáticos sobre adultos de moscabranca. Butirato de sacarose, caprato, octanoato, palmitato, oleato, actaacetato, ftlato, benzoato e diacetato hexaisobutirato de sacarose foram testados. Soluções de éster de sacarose foram preparadas e aplicadas sobre adultos capturados em armadilhas adesivas utilizando Torre de Potter. Ésteres alifáticos de sacarose com longas cadeias foram mais efetivos contra mosca-branca e as maiores taxas de mortalidade foram obtidas com oleato e octanoato de sacarose. Uma vez que estes compostos são caracterizados como tensoativos, dodecilsulfato de sódio foi testado para comparação e não se observou qualquer efeito. Butirato de sacarose e outros poliésteres de sacarose alifáticos ou aromáticos foram praticamente inócuos para mosca-branca.

\section{ACKNOWLEDGMENT}

We thank A.R. Generoso for the technical assistance during the preliminary trials and review of the manuscript. This study was partly funded by FAPESP (01/07093-7).

\section{REFERENCES}

Abbott , W. S. (1925), A method of computing the effectiveness of an insecticide. J. Econ. Entomol., 18, 265-267.

Brown, J.K. and Czosnek, H. (2002), Whitefly transmission of plant viruses. Adv. Bot. Res., 36, 65100.

Chortik, O.T.; Kays, S.J.; Teng, Q. (1997), Characterization of insecticidal sugar esters of Petunia. J. Agric. Food Chem., 45, 270-275.

Chortik, O.T.; Pomonis, J.G.; Johnson, A.W. (1996), Syntheses and characterizations of insecticidal sucrose esters. J. Agric. Food Chem., 44, 1551-1557.

Denholm, I.; Devine, G.J.; Gorman, K.; Horowitz, A.R. (2003), Insecticide resistance in Bemisia: a global perspective. Annals of the $3^{\text {rd }}$ International Bemisia Workshop., p. 113.

Drost, Y.C.; van Lenteren, J.C.; van Roermund, H.J.W. (1998), Life-history parameters of different biotypes of Bemisia tabaci (Hemiptera: Aleyrodidae) in relation to temperature and host plant: a selective review. Bull. Entomol. Res., 88, 219-229.

Fernandes, O.A. (1998), Pragas do melão - Cucumis melo L. In: Braga Sobrinho, R.; Cardoso, J.E.; Freire, F.C.O. (Ed.) Pragas de fruteiras tropicais de 
importância agroindustrial. CNPAT/EMBRAPA, Fortaleza, CE. p. 181-189.

Gaertner, V.R. (1961), Sucrose ether-linked and esterlinked surfactants. J. Am. Oil Chem. Soc., 38, 410418.

Gunning, R. (2003), Insecticide resistance and resistance management in cotton populations of Bbiotype Bemisia tabaci in Australia. Annals of the $3^{\text {rd }}$ International Bemisia Workshop., p. 116.

Liu, T.X.; Stansly, P.A.; Chortyk, O.T. (1996), Insecticidal activity of natural and synthetic sugar esters against Bemisia argentifolii (Homoptera: Aleyrodidae). J. Econ. Entomol., 89, 1233-1239.

Lourenção, A.L. and Nagai, H. (1994), Surtos populacionais de Bemisia tabaci no Estado de São Paulo. Bragantia, 53, 53-59.

Michaud, J.P. and McKenzie, C.L. (2004), Safety of a novel insecticide sucrose octanoate to beneficial insects in Florida citrus. Fla. Entomol., 87, 6-9.

Peterson, J.K.; Harrison, H.F.; Chortyk, O.T. (1997), Effects of various synthetic sucrose esters on weed seed germination and crop growth: structure-activity and dose-response relationships. J. Agric. Food Chem., 45, 4833-4837.

Polat, T. and Linhardt, R.J. (2001), Syntheses and applications of sucrose-based esters. J. Surf. Detergents, 4, 415-421.

Prabhaker, N; Toscano, N; Castle, S.; Henneberry, T. (2003), Impact of insecticide resistance on chemical control of Bemisia tabaci. Annals of the $3^{\text {rd }}$ International Bemisia Workshop, p. 120.

Puterka, G.J.; Farone, W.; Palmer, T.; Barrington, A. (2003), Structure-function relationships affecting the insecticidal and miticidal activity of sugar esters. Ecotoxicology, 96, 636-644.

Puterka, G.J. and Severson, R.F. (1995), Activity of sugar esters isolated from leaf trichomes of Nicotiana gossei to pear psylla (Homoptera: Psyllidae). J. Econ. Entomol., 88, 615-619.

Rodriguez, C.; Acharya, D.P.; Hinata, S.; Ishitobi, M.; Kunieda, H. (2003), Effect of ionic surfactants on the phase behavior and structure of sucrose ester/water/oil systems. J. Colloid Interface Sci., 262, 500-505.

SAS Institute (1996), Proprietary software release 6.12. SAS Institute, Cary, NC, USA.

Schuchardt, U.; Sercheli, R.; Vargas, R.M. (1998), Transesterification of vegetable oils: a review. $J$. Braz. Chem. Soc., 9, 199-210.

Sundaramurthy, V.T. (1992), Upsurgence of whitefly Bemisia tabaci Gen. in the cotton ecosystem in India. Outlook on agriculture, 21, 109-115.

Thévenet, S.; Wernicke, A.; Belniak, S.; Descotes, G.; Bouchu, A.; Queneau, Y. (1999), Esterification of unprotected sucrose with acid chlorides in aqueous medium: kinetic reactivity versus acyl- or alkyloxycarbonyl-group migrations. Carbohyd. Res., 318, 52-66.

Xia, X. and Johnson, A.W. (1997), Effects of leaf surface moisture and relative humidify on the efficacy of sugar esters from Nicotiana gossei against the Tobacco Aphid (Homoptera: Aphididae). J. Econ. Entomol., 90, 1010-1014.

Xia, X.; Johnson, A.W.; Chortik, O.T. (1997), Enhanced toxicity of sugar esters to the Tobacco Aphid (Homoptera: Aphididae) using humectantes. $J$. Econ. Entomol., 90, 1015-1021.

Received: March 29, 2006; Revised: November 19, 2007; Accepted: April 25, 2008. 


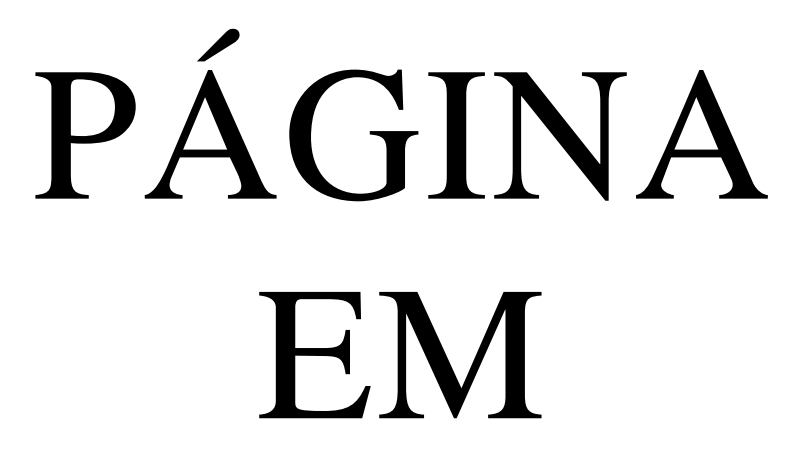

BRANCO 